\title{
INFLUENCE OF DEVELOPMENTAL STAGE ON SENSITIVITY TO AMMONIUM NITRATE OF AQUATIC STAGES OF AMPHIBIANS
}

\author{
Manuel E. Ortiz-Santaliestra, $* \dagger$ Adolfo Marco, $\neq$ María José Fernández, $\dagger$ and Miguel Lizana $\dagger$ \\ $\dagger$ Department of Animal Biology, University of Salamanca, Campus Miguel de Unamuno, Salamanca 37007, Spain \\ \$Doñana Biological Station, Spanish Council for Scientific Research, P.O. Box 1056, Sevilla 41013, Spain
}

(Received 13 January 2005; Accepted 24 June 2005)

\begin{abstract}
In static renewal experiments, we studied how developmental stage influences the effect of ammonium nitrate on embryonic and larval stages of anuran amphibians. The observed lethal effects caused by ammonium nitrate increased with both concentration and duration of exposure. Significant differences were observed in sensitivity to ammonium nitrate as a function of developmental stage in Discoglossus galganoi, Pelobates cultripes, and Bufo calamita. In D. galganoi and P. cultripes, younger individuals displayed greater acute effects from the chemical fertilizer compared with older individuals. For example, $100 \%$ of $P$. cultripes hatchlings died after $4 \mathrm{~d}$ of exposure to a nominal concentration of $225.8 \mathrm{mg} \mathrm{N}-\mathrm{NO}_{3} \mathrm{NH}_{4} / \mathrm{L}$, whereas less than $40 \%$ of individuals from older larval stages died when exposed to this concentration. A delay of $4 \mathrm{~d}$ in the beginning of the exposure to the chemical was enough to cause significant differences in sensitivity. Bufo calamita showed a higher sensitivity in later larval stages after $12 \mathrm{~d}$ of exposure. Hyla meridionalis and B. calamita were less sensitive than the other two species. Peak ammonium nitrate concentrations usually occur when amphibians are breeding and, thus, when the most sensitive aquatic stage is in the water. The developmental stage of the test animals should be considered when evaluating the risk of ammonium nitrate to amphibians.
\end{abstract}

Keywords-Amphibians Ammonium nitrate Life-stage sensitivity Development Nitrogen pollution

\section{INTRODUCTION}

Elevated concentrations of nitrate or ammonia in surface water of agricultural lands may be hazardous to many wildlife species (e.g., [1,2]). Nitrate-related compounds may have negative effects on wildlife, such as methemoglobinemia or carcinogenesis [2], and acute exposure to ammonium nitrate fertilizer has a negative effect on adult frogs [3]. Aquatic larval stages of some amphibians also are susceptible to the negative effects of ammonia, nitrate, and nitrite (e.g., [4,5]). The earliest stages of many amphibians are restricted to aquatic environments and are susceptible to absorption or ingestion of toxic compounds from the water or substrate [6]. Recent data suggest that nitrogen-based fertilizers may be contributing to the decline of some amphibian populations in agricultural lands $[3,5,6]$. However, a strong tolerance of some amphibians to environmental levels of these compounds has been documented $[7,8]$.

This apparent paradox may be explained by interspecific, and even geographical intraspecific, variability of sensitivity to ammonia or nitrate. This variability in the sensitivity of amphibians to water pollution has been demonstrated for other chemicals. For example, Bridges and Semlitsch [9] demonstrated a geographical variability in time to death among nine ranid species, as well as among several Rana sphenocephala populations, exposed to the pesticide carbaryl. In addition to this inter- or intraspecific variability, we suggest that the developmental stage of test animals, which varied widely among the different studies that have analyzed the sensitivity of amphibians to nitrogen-based compounds [3,5-8], could be responsible, in part, for the observed differences in sensitivity, because it has been demonstrated in other studies conducted with agricultural pesticides [10].

\footnotetext{
* To whom correspondence may be addressed (meortiz@usal.es).
}

Most ecotoxicological studies with anuran amphibians are conducted after larvae gills become internalized, at Gosner stages 25 to 32 [11]. However, these developmental stages might not be the most sensitive to the chemical fertilizers. Smaller larvae have a higher surface to volume ratio, which can be related to a greater absorption of contaminants relative to body mass and, thus, with a higher sensitivity to these compounds [12]. Gills also can play an important role in larval sensitivity to toxic chemicals. In fish, for example, it has been demonstrated that nitrite is concentrated in the blood by an active transport system in the gills [2]. In larval amphibians, gills are responsible for ion exchange [13], so they constitute one of the main routes of absorption of toxic chemicals into the organism. Because newly hatched anuran larvae have external gills that become internalized during the early larval development [14], the first stages after hatching would be expected to be more sensitive to nitrogenous compounds compared with later stages, when gills are covered by the skin. For this reason, we hypothesized that the embryonic or earliest larval stages of anuran amphibians would be more vulnerable to ammonium nitrate compared with medium or late larval stages.

Because of spring runoff, maximum levels of nitrogen fertilizers in surface waters may coincide with these earliest amphibian stages $[6,12]$. These peaks of nitrogen levels in surface water are related to the amount of drainage [15], and they occur during the first rains after the application of fertilizers [16]. Fertilization in temperate regions occurs mainly during late winter, so the first spring rains will increase nitrate drainage into bodies of water used by amphibians. This peak of nitrogen fertilizer levels is not expected to last a long time [1], but because it is related to the first spring rains, it can occur during the precipitation-induced breeding season of many amphibian species. 
To test the hypothesis that developmental stage influences the sensitivity of amphibians to ammonium nitrate, we studied the effect of the chemical on Iberian painted frog (Discoglossus galganoi), western spadefoot toad (Pelobates cultripes), natterjack toad (Bufo calamita), and southern tree frog (Hyla meridionalis) eggs and larvae using static renewal laboratory experiments.

\section{MATERIALS AND METHODS}

\section{Study species}

We collected eggs of the four species from several ponds in Almonte, Huelva, Spain, in January 2002, November 2002, and January 2003. We selected these ponds because they do not present nitrate or ammonium pollution, which could have resulted in the selection of the most tolerant individuals before egg collection. For each species, eggs from at least three different masses were collected during the early stages of development (Gosner stages 10 and 11 , corresponding to the early gastrula stage) [17], except for D. galganoi, which were collected at Gosner stage 21, when the cornea becomes transparent [17]. Segments of clutch were carried to the laboratory, where the experiments were developed.

\section{Experimental procedures}

To test the influence of developmental stage on sensitivity to ammonium nitrate, eggs and larvae of each species were exposed in static renewal laboratory tests [18] to identical ammonium nitrate concentrations and exposure times but at different stages of their embryonic and larval development. Experiments were conducted in the laboratory at $18^{\circ} \mathrm{C}$ under natural light and photoperiod. Eggs from all the clutches of each species collected in the field were placed in 3.4-L tanks containing $2 \mathrm{~L}$ of dechlorinated tap water and varying levels of ammonium nitrate. In every experiment, each tank was randomly assigned to one concentration and exposure starting stage in a block design. Each treatment (stage $\times$ concentration) was replicated three times. Exposed and nonexposed individuals were kept under the same experimental conditions.

We designed two different sets of experiments. In the first, we exposed $D$. galganoi and $H$. meridionalis at two different developmental stages to four concentrations of ammonium nitrate (nominal concentrations of $0,22.6,45.2$, and $90.3 \mathrm{mg}$ $\mathrm{N}-\mathrm{NO}_{3} \mathrm{NH}_{4} / \mathrm{L}$ ) for $15 \mathrm{~d}$. We used an additional nominal concentration of $180.6 \mathrm{mg} \mathrm{N}-\mathrm{NO}_{3} \mathrm{NH}_{4} / \mathrm{L}$ only in D. galganoi. Exposure to ammonium nitrate in D. galganoi started at Gosner stage 21 , corresponding to when the cornea becomes transparent, and stage 24, corresponding to development of the operculum [17]. Hyla meridionalis was exposed to the chemical from Gosner stage 13 (neural plate) or stage 19, when the heart starts beating [17]. Initial stages for exposure of each species were selected from the stage at which eggs were collected in the field. The entire duration of experiments in the first set was 30 d. Early staged individuals of each species were exposed during days 1 to 15 , and later-staged individuals were tested from days 16 to 30 .

In the second set of experiments, we exposed $P$. cultripes and $B$. calamita eggs or larvae at four different developmental stages to three levels of ammonium nitrate (nominal concentrations of $0,90.3$, and $225.8 \mathrm{mg} \mathrm{N}-\mathrm{NO}_{3} \mathrm{NH}_{4} / \mathrm{L}$ ) for $12 \mathrm{~d}$. Embryos were first exposed to ammonium nitrate at Gosner stage 13. Later exposures began when individuals were at Gosner stages 19,21 , and 24 . The experiments lasted for $24 \mathrm{~d}$, with staggered exposure periods. Individuals tested at Gosner stage 13 were exposed during days 1 to 12 , those at Gosner stage 19 during days 5 to 16 , those at Gosner stage 21 during days 9 to 20, and those at Gosner stage 24 during days 13 to 24 . The jelly coats of eggs were kept intact in all experiments to assess realistic differences in sensitivity among individuals exposed from embryonic or larval stages. At the beginning of the experiments, 15 eggs ( 5 from each clutch $\times 3$ clutches $)$ in the first set or 20 eggs ( 4 from each clutch $\times 5$ clutches) in the second set were randomly assigned to each tank. Each treatment (initial stage of exposure and ammonium nitrate nominal concentration) was replicated three times. The two experimental designs were made to use either the ammonium nitrate concentration (first set) or the initial stage of exposure (second set) as the main source of variation.

Ammonium nitrate (purity, 99\%; Merck $\mathrm{KgaA}^{\circledR}$, Darmstadt, Germany) was used to make up a $4.5 \mathrm{~g} \mathrm{~N}-\mathrm{NO}_{3} \mathrm{NH}_{4} / \mathrm{L}$ stock solution that was pipetted into experimental tanks to obtain the final concentrations. We selected the nominal concentration of $22.6 \mathrm{mg} \mathrm{N}-\mathrm{NO}_{3} \mathrm{NH}_{4} / \mathrm{L}$ from the nitrate legal maximum intended for human consumption [19], two environmentally relevant nitrate levels (45.2 and $90.3 \mathrm{mg} \mathrm{N}-\mathrm{NO}_{3} \mathrm{NH}_{4} /$ L), and a high chemical level (180.6 or $225.8 \mathrm{mg} \mathrm{N}-\mathrm{NO}_{3} \mathrm{NH}_{4} /$ L) as a positive control. We did not use this positive control in the experiment with $H$. meridionalis, however, because the low number of eggs collected did not allow an additional ammonium nitrate treatment. Larvae were fed ad libitum with lettuce previously washed with water and boiled for $5 \mathrm{~min}$. Solutions were replaced and tanks cleaned every $5 \mathrm{~d}$ in the first set or every $4 \mathrm{~d}$ in the second set. Levels of ammonia or nitrate were not tested during the experiment, because water volume was sufficiently high in comparison to the mass of tadpoles that no differences should have occurred among age groups in ammonium production. This design would represent a "pulse" exposure [20] similar to what happens in the amphibian breeding sites, where peak levels (treated here as nominal concentrations) occur just after fertilizer runoff and then decrease with time.

Water temperature varied less than $1{ }^{\circ} \mathrm{C}$ within the same experiment, and its range for all four experiments remained between 16 and $19^{\circ} \mathrm{C}$. Water $\mathrm{pH}$ was monitored daily with a pH meter Hanna HI-8314N ${ }^{\circledR}$ (Hanna Instruments Spain, Eibar, Spain). Overall $\mathrm{pH}$ in the four experiments varied between 7.20 and 7.40. Dissolved oxygen was measured with an Oximeter Handylab OX1/Set ${ }^{\circledR}$ (Schott-Geräte, Hofheim, Germany). Overall dissolved oxygen levels inside every water renewal period varied between 7.10 and $6.03 \mathrm{mg} / \mathrm{L}$ for all four experiments. Total hardness of the test water was measured by the complexometric titration method [21] and varied between 0.89 and $1.07 \mathrm{mmol} / \mathrm{L}$. Larval mortality was monitored, and dead larvae were removed every $24 \mathrm{~h}$. Total body length (mouth to tail tip) of the surviving tadpoles was measured at the end of the experiments with an electronic digital caliper (Stainless Hardened; Acha S.L. ${ }^{\circledR}$, Eibar, Spain) to the nearest $0.01 \mathrm{~mm}$. This measure was not taken in $H$. meridionalis because of a premature release of one test group.

\section{Analysis of data}

To determine the effect of ammonium nitrate on amphibian mortality and the influence of developmental stage on this toxicity, we used, for each species, a two-way, repeated-measures analysis of variance (ANOVA) with cumulative mortality rates (arcsine of square-root transformed) after 2, 4, 8, 12, and 
Table 1. Results of two-way analysis of variance to analyze effects of developmental stage on sensitivity of four amphibian species to ammonium nitrate ${ }^{\mathrm{a}}$

\begin{tabular}{llrrrr}
\hline \multirow{2}{*}{ Species } & \multicolumn{2}{c}{ Mean } & & \\
\hline Discoglossus galganoi & Source of variation & squares & $d f$ & \multicolumn{1}{c}{$F$} & \multicolumn{1}{c}{$p$} \\
& Concentration & 1.498 & 4 & 32.439 & $<0.001$ \\
& Stage & 1.016 & 1 & 21.998 & $<0.001$ \\
& Concentration $\times$ stage & 0.309 & 4 & 6.684 & 0.001 \\
& Error & 0.047 & 20 & & \\
Pelobates cultripes & Concentration & 7.155 & 2 & 346.074 & $<0.001$ \\
& Stage & 1.062 & 3 & 51.377 & $<0.001$ \\
& Concentration $\times$ stage & 0.626 & 4 & 30.288 & $<0.001$ \\
Bufo calamita & 0.021 & 20 & & \\
& Error & 1.238 & 2 & 58.926 & $<0.001$ \\
& Concentration & 0.095 & 3 & 4.539 & 0.015 \\
Hyla meridionalis & Ctage & 0.105 & 3 & 4.979 & 0.011 \\
& Error & 0.021 & 18 & & \\
& Concentration $\times$ stage & 0.334 & 3 & 1.596 & 0.230 \\
& Stage & 0.690 & 1 & 3.297 & 0.088 \\
& Concentration $\times$ stage & 0.450 & 3 & 2.152 & 0.134 \\
& Error & 0.209 & 16 & & \\
\hline
\end{tabular}

${ }^{a}$ Dependent variables are mortality rates (arcsine of square-root transformed) with exposure duration as a repeated measure.

$15 \mathrm{~d}$ of exposure as dependent variables and nitrogen concentration and developmental stage at the beginning of the exposure as categorical variables. To determine the age-related effects of ammonium nitrate on larval size, we used a twoway ANOVA with larval length as dependent variable and pollutant concentration and stage of exposure as categorical variables. We used post hoc honestly significantly different Tukey tests for pairwise comparisons [22]. Kolmogorov-Smirnoff $Z$ tests to check normality of transformed mortality rates and larval length were conducted before ANOVAs. In all cases, the $Z$ test resulted in $p$ values of greater than 0.050 . The software SPSS 11.5 for Windows (SPSS ${ }^{\circledR}$, Chicago, IL, USA) was used for statistical analysis.

\section{RESULTS}

Mortality in control tanks was less than $5 \%$ in all cases. In tanks where individuals were not exposed from the beginning of the experiment, no mortality was recorded before the exposure.

\section{Discoglossus galganoi experiment}

Ammonium nitrate produced lethal effects on $D$. galganoi larvae (Table 1). Individuals exposed to $90.3 \mathrm{mg} \mathrm{N}-\mathrm{NO}_{3} \mathrm{NH}_{4} /$
L showed $31.1 \%$ mortality at the end of the experiment. Overall larval size was significantly lower in individuals exposed to $90.3 \mathrm{mg} \mathrm{N}-\mathrm{NO}_{3} \mathrm{NH}_{4} / \mathrm{L}$ (Table 2), with a body length $23.4 \%$ smaller than that of controls. An interaction between ammonium nitrate and developmental stage at the beginning of exposure was detected in this species (Table 1). At the end of the experiment, mortality in tadpoles exposed to $90.3 \mathrm{mg} \mathrm{N}$ $\mathrm{NO}_{3} \mathrm{NH}_{4} / \mathrm{L}$ from Gosner stage 24 hardly surpassed $6 \%$, but more than $50 \%$ of individuals exposed to that level from Gosner stage 21 died (Fig. 1a). Discoglossus galganoi also showed an age-related effect of ammonium nitrate on larval length (Table 2). Individuals exposed from Gosner stage 21 to ammonium nitrate concentrations greater than $45.2 \mathrm{mg} \mathrm{N}$ $\mathrm{NO}_{3} \mathrm{NH}_{4} / \mathrm{L}$ were significantly smaller than those exposed from Gosner stage 24 (Fig. 2).

\section{Hyla meridionalis experiment}

Ammonium nitrate exposure and the initial stage at which tadpoles were exposed to the fertilizer had no effect on sensitivity of $H$. meridionalis (Table 1 ). However, despite the absence of effects, we cannot consider $H$. meridionalis as the most tolerant species, because the highest level used in this

Table 2. Results of two-way analysis of variance to analyze the effects of developmental stage and ammonium nitrate on larval length of three amphibian species

\begin{tabular}{llrrrr}
\hline & & Mean & & \\
Species & Source of variation & squares & $d f$ & $F$ & \multicolumn{1}{c}{$p$} \\
\hline Discoglossus galganoi & Concentration & 21.313 & 4 & 87.001 & $<0.001$ \\
& Stage & 2.578 & 1 & 10.523 & 0.005 \\
& Concentration $\times$ stage & 1.682 & 3 & 6.865 & 0.003 \\
& Error & 0.245 & 18 & & \\
Pelobates cultripes & 72.386 & 5 & 46.427 & $<0.001$ \\
& Concentration & 13.918 & 5 & 8.927 & $<0.001$ \\
& Stage & 3.534 & 9 & 2.267 & 0.034 \\
Bufo calamita & 1.559 & 45 & & \\
& Error & 30.525 & 2 & 138.154 & $<0.001$ \\
& Concentration $\times$ stage & 1.205 & 3 & 5.456 & 0.010 \\
& Stage & 0.654 & 3 & 2.959 & 0.066 \\
& Concentration $\times$ stage & 0.221 & 15 & & \\
\hline
\end{tabular}




\section{a) Discoglossus galganoi}

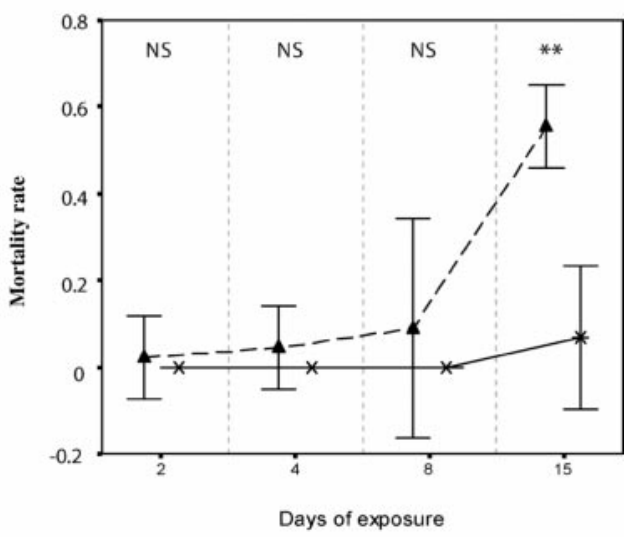

b) Pelobates cultripes

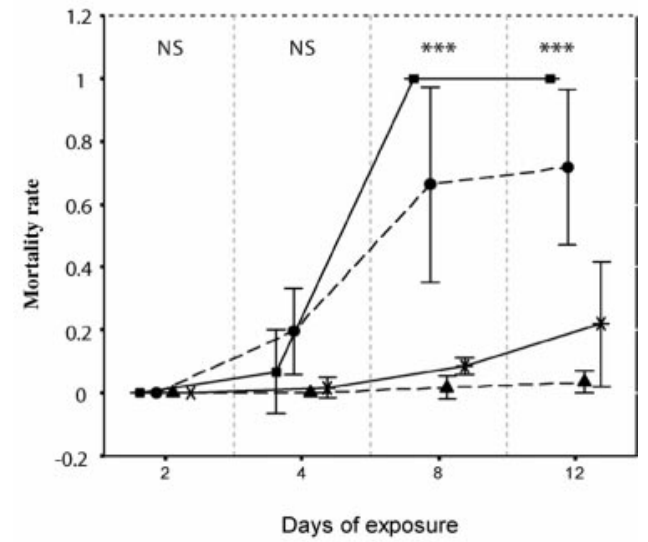

c) Bufo calamita

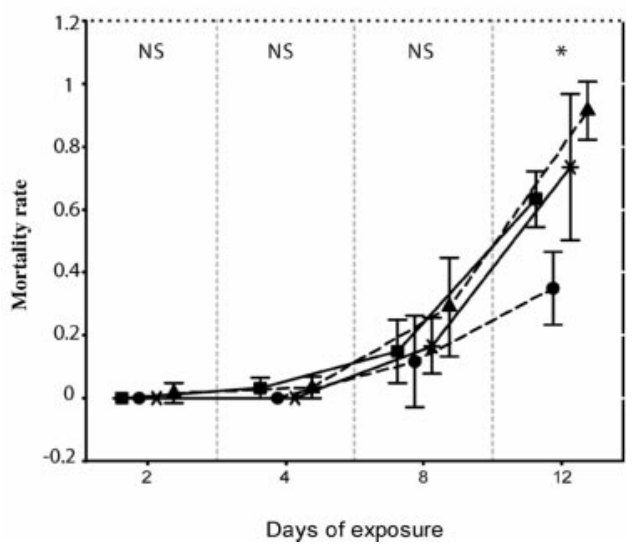

Fig. 1. Mortality ( \pm standard deviation) caused by ammonium nitrate in tadpoles of three amphibian species. Mortality in (a) Discoglossus galganoi exposed to $90.3 \mathrm{mg} \mathrm{N}-\mathrm{NO}_{3} \mathrm{NH}_{4} / \mathrm{L}$, (b) Pelobates cultripes exposed to $90.3 \mathrm{mg} \mathrm{N}-\mathrm{NO}_{3} \mathrm{NH}_{4} / \mathrm{L}$, and (c) Bufo calamita exposed to $225.8 \mathrm{mg} \mathrm{N}-\mathrm{NO}_{3} \mathrm{NH}_{4} / \mathrm{L}$. Continuous lines with square markers correspond to individuals exposed from Gosner stage 13, dashed lines with circles to individuals exposed from Gosner stage 19, dashed lines with triangles to individuals exposed from Gosner stage 21, and continuous lines with asterisks to individuals exposed from Gosner stage 24 . Results of analysis of variance to compare mortality among age groups are shown. $* p<0.05, * * p<0.01, * * * p<0.001 . \mathrm{NS}=$ not significant $(p>0.05)$.

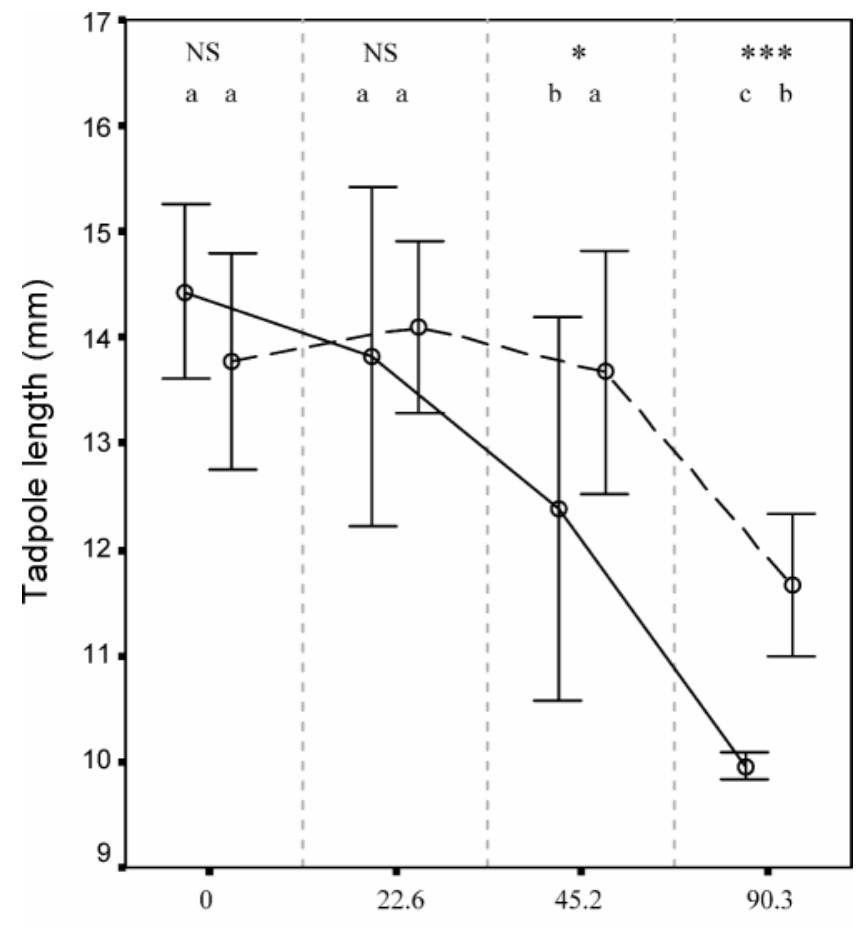

Ammonium nitrate concentration ( $\mathrm{mg} \mathrm{N} / \mathrm{L}$ )

Fig. 2. Influence of ammonium nitrate on larval length ( \pm standard deviation) of Discoglossus galganoi. The continuous line represents the hatchling length of individuals that began the exposure to the chemical at Gosner stage 21 . The dashed line corresponds to individuals that began the exposure at Gosner stage 24. Significance levels and homogeneous groups of post hoc pairwise comparisons (Tukey tests) for the effect of age on each concentration are addressed. Different letters indicate significant differences. ${ }^{*} p<0.05, * * * p<0.001$. $\mathrm{NS}=$ not significant $(p>0.05)$.

experiment (90.3 mg N-NO $\left.\mathrm{NH}_{4} / \mathrm{L}\right)$ did not produce any effect in B. calamita tadpoles.

\section{Pelobates cultripes experiment}

Ammonium nitrate produced significant mortality in $P$. cultripes (Table 1), with $49.2 \%$ mortality at $90.3 \mathrm{mg} \mathrm{N}-\mathrm{NO}_{3} \mathrm{NH}_{4} /$ $\mathrm{L}$ at the end of the experiment. Larval length also was affected by the exposure to fertilizer (Table 2). Individuals exposed to $90.3 \mathrm{mg} \mathrm{N}-\mathrm{NO}_{3} \mathrm{NH}_{4} / \mathrm{L}$ were $23 \%$ shorter than controls. We also detected differences in sensitivity among age groups in this species (Table 1). At the end of the experiment, individuals exposed from Gosner stage 13 to $90.3 \mathrm{mg} \mathrm{N}-\mathrm{NO}_{3} \mathrm{NH}_{4} / \mathrm{L}$ were the most sensitive, followed by those exposed from Gosner stage 19 (Fig. 1b). However, after only $4 \mathrm{~d}$ of exposure to $225.8 \mathrm{mg} \mathrm{N}-\mathrm{NO}_{3} \mathrm{NH}_{4} / \mathrm{L}$, tadpoles exposed from Gosner stage 19 were far more sensitive than those exposed from Gosner stage 13 (100 and 7.3\% mortality, respectively). The effects of ammonium nitrate on larval size also were affected by developmental stage (Table 2). At $90.3 \mathrm{mg} \mathrm{N}-\mathrm{NO}_{3} \mathrm{NH}_{4} / \mathrm{L}$, larval length of survivors exposed from Gosner stage 19 was significantly smaller than that of individuals exposed from later developmental stages (Fig. 3).

\section{Bufo calamita experiment}

Ammonium nitrate affected both survivorship (Table 1) and larval length (Table 2) of B. calamita. Nevertheless, lethal effects were only observed under exposure to the highest ammonium nitrate level (225.8 $\left.\mathrm{mg} \mathrm{N}-\mathrm{NO}_{3} \mathrm{NH}_{4} / \mathrm{L}\right)$, with $65.8 \%$ 


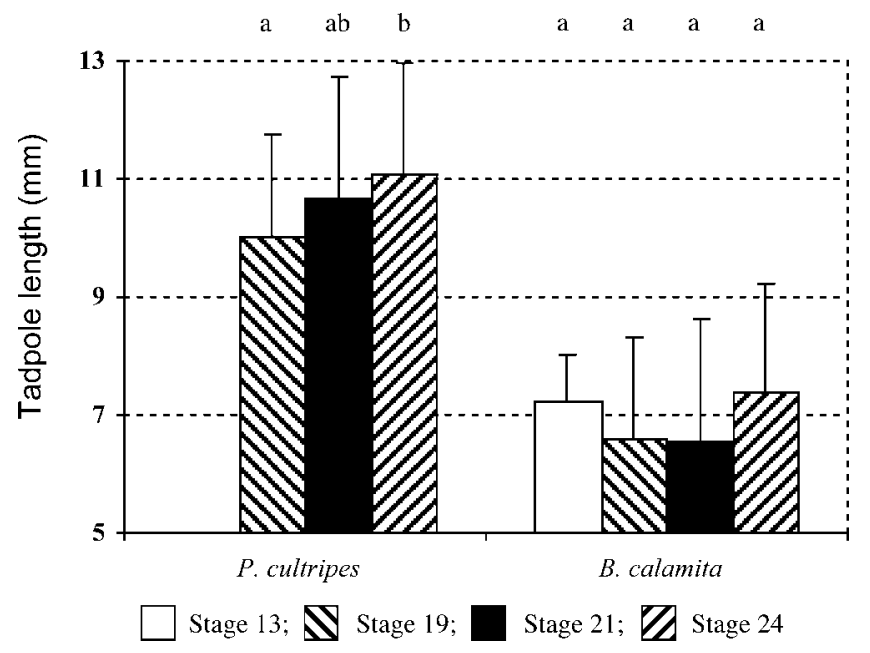

Fig. 3. Larval length ( \pm standard error) shown by two amphibian species after exposure to $90.3 \mathrm{mg} \mathrm{N}-\mathrm{NO}_{3} \mathrm{NH}_{4} / \mathrm{L}$. Larvae from all treatments within the same experiment were measured at the same time, coinciding with the last day of experiment. The legend indicates initial stages of exposure. Lowercase letters indicate homogenous groups of pairwise comparisons (Tukey tests) for the effect of age on length All Pelobates cultripes tadpoles exposed from Gosner stage 13 died before the end of the experiment, so no data are included from that age group.

mortality. Larval length was $26.6 \%$ smaller in tadpoles exposed to $90.3 \mathrm{mg} \mathrm{N}-\mathrm{NO}_{3} \mathrm{NH}_{4} / \mathrm{L}$ than in controls. Bufo calamita also displayed an effect of developmental stage on sensitivity to ammonium nitrate (Table 1). Opposite to what was observed with D. galganoi and P. cultripes, B. calamita exposed from later developmental stages was the most sensitive. Tadpoles exposed to $225.8 \mathrm{mg} \mathrm{N}-\mathrm{NO}_{3} \mathrm{NH}_{4} / \mathrm{L}$ from Gosner stage 21 were significantly more sensitive than those exposed from earlier stages (Fig. 1c). Interaction between ammonium nitrate and developmental stage did not produce significant effects on larval size of $B$. calamita survivors (Table 2).

\section{DISCUSSION}

We have reported that ammonium nitrate can be seriously hazardous for amphibian survival, as has been suggested previously [4-6]. In a recent study, we assessed the sensitivity to ammonium nitrate of $P$. cultripes and $B$. calamita populations from northwestern Spain [23]. In that work, both species showed sublethal effects after $15 \mathrm{~d}$ of exposure to a nominal concentration of $90.3 \mathrm{mg} \mathrm{N}-\mathrm{NO}_{3} \mathrm{NH}_{4} / \mathrm{L}$. We are unaware of any published data regarding the sensitivity of the other studied species to nitrogenous fertilizers. We can observe from the literature a high variability in the sensitivity of amphibians to ammonium nitrate. Thus, whereas Berger [24] found significant mortality in European green frogs of the Rana esculenta complex after $4 \mathrm{~d}$ of exposure to $20 \mathrm{mg} \mathrm{NO} \mathrm{NH}_{4} / \mathrm{L}$ (7 mg N-NO $\mathrm{NH}_{4} / \mathrm{L}$ ), mortality did not occur until exposure at $387.5 \mathrm{mg} \mathrm{NO}-\mathrm{NO}_{3} \mathrm{NH}_{4} / \mathrm{L}\left(175 \mathrm{mg} \mathrm{N}-\mathrm{NO}_{3} \mathrm{NH}_{4} / \mathrm{L}\right)$ in Triturus helveticus [12].

The negative effect of ammonium nitrate on growth rate also has been observed in a huge amount of amphibian species. For example, Ortiz et al. [23] obtained a smaller size of $D$. galganoi and B. calamita larvae exposed to $200 \mathrm{mg} \mathrm{NO} / \mathrm{L}$ (90.3 mg N-NO $\mathrm{NO}_{3} \mathrm{NH}_{4} / \mathrm{L}$ ), whereas effects on $P$. cultripes larval size were observed under exposure to $22.6 \mathrm{mg} \mathrm{N}-\mathrm{NO}_{3} \mathrm{NH}_{4} / \mathrm{L}$. However, $\mathrm{Xu}$ and Oldham [25] found an opposite effect of low ammonium nitrate levels in larval size of the common toad, Bufo bufo. Concentrations of $22.6 \mathrm{mg} \mathrm{N}-\mathrm{NO}_{3} \mathrm{NH}_{4} / \mathrm{L}$ resulted in bigger tadpoles compared with controls. Harmless field nitrate levels could be advantageous for amphibian larvae by favoring the growth of larval food, such as algae and other aquatic vegetation, although this possibility may be rejected in the experimental tests because of the high frequency of water renewal.

The present study suggests an age-dependent sensitivity of amphibian embryos and larvae to short ammonium nitrate exposures. Ammonium nitrate produced higher mortality of $D$. galganoi and $P$. cultripes exposed from Gosner stage 13 than in those exposed from later developmental stages at $90.3 \mathrm{mg}$ $\mathrm{N}-\mathrm{NO}_{3} \mathrm{NH}_{4} / \mathrm{L}$. A review of the literature about experiments in which amphibians were exposed to nitrogen compounds seems to point toward a trend of age-related sensitivity. For example, $\mathrm{Xu}$ and Oldham [25] found in B. bufo tadpoles exposed from Gosner stage 32 a mortality rate of $21 \%$ after $30 \mathrm{~d}$ of exposure to $100 \mathrm{mg} \mathrm{NO}_{3}^{-} / \mathrm{L}\left(45.2 \mathrm{mg} \mathrm{N}-\mathrm{NO}_{3} \mathrm{NH}_{4} / \mathrm{L}\right)$. In a recent study [23], we observed a higher sensitivity to ammonium nitrate of B. bufo embryos and larvae, with $20 \%$ mortality of individuals exposed from Gosner stage 12 after $15 \mathrm{~d}$ of exposure to 50 $\mathrm{mg} \mathrm{NO}-/ \mathrm{L}\left(22.6 \mathrm{mg} \mathrm{N}-\mathrm{NO}_{3} \mathrm{NH}_{4} / \mathrm{L}\right)$. Stronger effects of some contaminants in individuals exposed during earlier stages have been reported by some authors. Dial and Dial [26] found that diquat and paraquat pesticides were more toxic to Rana pipiens embryos than to 15-d-old tadpoles.

We also observed a smaller size in D. galganoi and $P$. cultripes tadpoles exposed to ammonium nitrate from earlier stages. A decrease in food ingestion as a result of lost activity or an excessive energetic investment in detoxifying mechanisms, such as the urea-ornithine cycle [27], would be some of the possible causes for the smaller size of exposed individuals. Thus, any of these mechanisms should have affected, in a greater way, individuals exposed from earlier developmental stages. Unfortunately, nothing is known about how these effects can vary throughout the embryonic and larval development of amphibians. A bigger size at metamorphosis has been related to a higher survival rate of postmetamorphic individuals (e.g., [28]), and individuals with higher developmental rates are expected to reach metamorphosis with a bigger body size. Therefore, effects of ammonium nitrate on larval size of individuals exposed from earlier stages would reduce the survival probabilities of these individuals. Nevertheless, because our experiments did not last until metamorphosis, we can hardly conclude anything regarding this question. Bridges [10] observed that $R$. sphenocephala exposed from eggs to carbaryl showed a smaller size at metamorphosis than did those exposed from later developmental stages, whereas Greulich and Pflugmacher [29] obtained the same result by exposing Rana arvalis to the pyrethroid $\alpha$-cypermethrin.

During the first $4 \mathrm{~d}$ of exposure, we found a higher sensitivity in $P$. cultripes exposed from Gosner stage 19, which hatched during that 4 -d period, than in those exposed from Gosner stage 13, which remained in embryonic stages during this period. Although the difference in the start of exposure between these two developmental stages was only $4 \mathrm{~d}$, this short period of time was enough to cause a differential effect among the two groups. Studies to assess the effects of nitrate compounds on amphibian aquatic stages usually are carried out with individuals close to Gosner stage 25 [5,6,25]. Our data stress the importance of assessing the environmental impact of pollutants on early life stages.

In some studies, posthatch larvae have been reported to be 
the stage of amphibian development most sensitive to pollutants. Herkovits and Pérez-Coll [30] demonstrated that early larval stages (Gosner stage 16) of Bufo arenarum were more sensitive to cadmium than were those of Gosner stages 3 and 12 (embryonic stages). The organophosphate parathion also produced a higher effect on 22-d-old larvae than in embryos of B. arenarum [31]. In general, effects of pesticides and herbicides on embryos are scarce compared with effects on early larval stages (e.g., [32,33]). Bridges [10] found that exposure of larval $R$. sphenocephala to carbaryl produced a lower survival rate, a higher percentage of animals showing deformity, and a longer time to metamorphosis compared with exposure of individuals to the pesticide during the embryonic stage. The higher sensitivity shown by newly hatched larvae in these studies, as in our $P$. cultripes experiment reported here, does not seem to result from the protection given by the gelatinous cover. Herkovits and Pérez-Coll [30] as well as Bridges [10] demonstrated that gelatinous matrix was not the cause of the higher tolerance of embryos to cadmium exposure and to carbaryl exposure, respectively. Nitrate compounds seem to be very permeable to the gelatinous matrix of amphibian eggs, because acute effects on this stage have been reported in other cases [4].

A higher metabolic detoxifying ability has been proposed as a cause for the higher tolerance of later larval stages to pollutants [34]. Tissue and organ development begins at fertilization and continues through metamorphosis. Incomplete tissue and organ differentiation could make individuals in the earlier larval stages more sensitive to pollutants [35]. Nitrate can be reduced to nitrite by the gut bacteria, resulting in methemoglobinemia (e.g., [36]). Moreover, nitrates in the acidic environment of the gut also may be converted to nitrosamines, which are carcinogenic [37]. Thus, the gut environment plays an important role in the main effects of nitrogen compounds. Gut differentiation during the late embryonic and early larval stages could then be the cause of the higher tolerance of $P$. cultripes embryos. Hecnar [6] indicated an effect of ammonium nitrate on the symbiotic gut bacteria involved in digestion, which could alter food ingestion by tadpoles. This also could explain the higher tolerance shown by embryos, because mortality was not detected before active feeding was observed. An effect of nitrates on osmoregulation has been detected in some freshwater organisms [38], including amphibians [6]. In older anuran tadpoles, gills are internal [14], but immediately after hatching, gills are external and in direct contact with the water [13]. An effect of nitrates on osmoregulation could be especially important during this stage. The progressive skin thickness during larval development could give a higher protection against osmoregulatory alteration and would explain the higher tolerance of late larval stages to the pollutant [13]. Another possible reason for the higher sensitivity during the late embryonic stages would be the effect of ammonium nitrate on the central nervous system. Hecnar [6] proposed this effect from the observations of irregular swimming, paralysis, and delayed responses to stimuli observed in tadpoles exposed to the fertilizer. This effect would make older embryos more sensitive than younger embryos, because differentiation of the neural tube happens during the late embryonic stages [17].

On the other hand, we have observed in B. calamita an age-effect trend different from those of the rest of the species. Individuals exposed to $225.8 \mathrm{mg} \mathrm{N}-\mathrm{NO}_{3} \mathrm{NH}_{4} / \mathrm{L}$ from Gosner stages 21 and 24 were more sensitive than those exposed from Gosner stages 13 and 19, although the differences were not as clear as those in the species with a higher sensitivity of younger individuals. Tadpoles of pond-inhabiting anuran species develop lungs early in their larval life. These tadpoles can then consume oxygen by gulping air as the amount of dissolved oxygen decreases. However, species of Bufo do not develop lungs until just before metamorphosis, so they are unable to gulp air during their larval stages [14]. Bufo calamita would then be more sensitive to the hypoxic conditions than the other three species tested, especially during later stages, when tadpoles consume more oxygen [13]. Although we did not observe any sign of anoxia, methemoglobinemia produced by nitrogenrelated compounds could have affected older $B$. calamita tadpoles in a greater way than those of the other three species.

Maximum levels of nitrogen fertilizers in surface water are related to timing of fertilizer application, precipitation, and irrigation. Because these maximum levels coincide with the first spring rains, which also induce migrations toward the breeding ponds and reproduction of many amphibian species, they are expected to affect the most sensitive stages when they appear in the water. Levels up to $90.3 \mathrm{mg} \mathrm{N}-\mathrm{NO}_{3} \mathrm{NH}_{4} / \mathrm{L}$ have been found in ponds where amphibians breed at several agricultural areas of Spain after fertilizer drainage by rains (M.E. Ortiz-Santaliestra et al., unpublished data). This level has been demonstrated to cause lethal effects during the most sensitive stages in embryo and larval development of $P$. cultripes and $D$. galagnoi as well as a reduction in B. calamita tadpole growth rate. Thus, although overall nitrate or ammonia levels in bodies of water are not usually high enough to kill amphibians, these pollutant peaks may occur when amphibians are most sensitive.

Fertilization practices in agricultural landscapes are the main source of nitrogen contamination in bodies of water used by amphibians [1]. Thus, it is necessary to assess the effects that fertilization timing can present to amphibian development and survival. We consider that for areas with endangered and sensitive amphibian species, a good agricultural practice would be to delay crop fertilization until the sensitive species have hatched, or at least until after the first spring rains that fill the ponds and induce amphibians to breed have happened. This measure would not necessarily reduce fertilizer efficiency (e.g., [39]), because it could improve the efficiency of fertilizers by avoiding losses caused by leaching or runoff [40] while minimizing their impact on amphibian survival and development.

Acknowledgement-We thank Wouter de Vries, Joan M. del Llano, Gonzalo Alarcos, Carmen Díaz-Paniagua, and Gwyn Jenkins for their help. Donald W. Sparling and two anonymous referees provided helpful comments to the manuscript. Funding was provided by the Regional Government of Castilla and León (project SA049/04) and Ministry of Education and Science of Spain (grant AP2001-2276 to M.E. Ortiz-Santaliestra).

\section{REFERENCES}

1. Bogardi I, Kuzelka RD, Ennenga WG. 1991. Nitrate Contamination: Exposure, Consequence, and Control, NATO ASI Series G-Ecological Sciences, Vol 30. Springer-Verlag, New York, NY, USA.

2. Lewis WM Jr, Morris DP. 1986. Toxicity of nitrite to fish: A review. Trans Am Fish Soc 115:183-194.

3. Oldham RS, Lathan DM, Hilton-Brown D, Towns M, Cooke AS, Burn A. 1997. The effect of ammonium nitrate fertilizer on frog (Rana temporaria) survival. Agric Ecosyst Environ 61:69-74.

4. Schuytema GS, Nebeker AV. 1999. Comparative effects of ammonium and nitrate compounds, on Pacific treefrog and African clawed frog embryos. Arch Environ Contam Toxicol 36:200206.

5. Marco A, Quilchano C, Blaustein AR. 1999. Sensitivity to nitrate 
and nitrite in pond-breeding amphibians from the Pacific Northwest, USA. Environ Toxicol Chem 18:2836-2839.

6. Hecnar SJ. 1995. Acute and chronic toxicity of ammonium nitrate fertilizer to amphibians from southern Ontario. Environ Toxicol Chem 14:2131-2137.

7. Johansson M, Rasanen K, Merila J. 2001. Comparison of nitrate tolerance between different populations of the common frog, Rana temporaria. Aquat Toxicol 54:1-14.

8. Sullivan KB, Spence KM. 2003. Effects of sublethal concentrations of atrazine and nitrate on metamorphosis of the African clawed frog. Environ Toxicol Chem 22:627-635.

9. Bridges CM, Semlitsch RD. 2000. Variation in pesticide tolerance of tadpoles among and within species of Ranidae and patterns of amphibian decline. Conserv Biol 14:1490-1499.

10. Bridges CM. 2000. Long-term effects of pesticide exposure at various life stages of the southern leopard frog (Rana sphenocephala). Arch Environ Contam Toxicol 39:91-96.

11. Devillers J, Exbrayat JM. 1992. Ecotoxicity of Chemicals to Amphibians. Gordan and Breach Science, Lyon, France.

12. Watt PJ, Jarvis P. 1997. Survival analysis in palmate newts exposed to ammonium nitrate agricultural fertilizer. Ecotoxicology 6:355-362.

13. McDiarmid RW, Altig R, eds. 1999. Tadpoles. The Biology of Anuran Larvae. University of Chicago Press, Chicago, IL, USA.

14. Duellman W, Trueb L. 1994. Biology of Amphibians. Johns Hopkins University Press, Baltimore, MD, USA.

15. Pratt PF. 1984. Nitrogen use and nitrate leaching in irrigated agriculture. In Hauck, RD, ed, Nitrogen in Crop Production. American Society of Agronomy, Madison, WI, pp 319-333.

16. Ritter WF, Scarborough RW, Chirnside AEM. 1991. Nitrate leaching under irrigated corn. Journal of Irrigation and Drainage Engineering 119:544-553.

17. Gosner KL. 1960. A simplified table for staging anuran embryos and larvae with notes on identification. Herpetologica 16:183190.

18. Stephen CE. 1975. Methods for acute toxicity tests with fish, macroinvertebrates and amphibians. EPA-660/3-75-009. U.S. Environmental Protection Agency, Corvallis, OR.

19. European Council. 1980. The directive on quality of water intended for human consumption. 80/778/EEC. Technical Report. Strasbourg, France.

20. Hatch AC, Blaustein AR. 2000. Combined effects of UV-B, nitrate and low $\mathrm{pH}$ reduce the survival and activity level of larval Cascades frogs (Rana cascadae). Arch Environ Contam Toxicol 39:494-499.

21. Skoog DA, West DM, Holler FJ, Crouch SR. 2004. Fundamentals of Analytical Chemistry, 8th ed. Brooks/Cole Thompson Learning, Pacific Grove, CA, USA.

22. Gad S, Weil CS. 1986. Statistics and Experimental Design for Toxicologists. Telford Press, Caldwell, NJ, USA.

23. Ortiz ME, Marco A, Saiz NI, Lizana M. 2004. Impact of am- monium nitrate on growth and survival of six European amphibians. Arch Environ Contam Toxicol 47:234-239.

24. Berger L. 1989. Disappearance of amphibian larvae in the agricultural landscape. Ecology International Bulletin 17:65-73.

25. Xu Q, Oldham RS. 1997. Lethal and sublethal effects of nitrogen fertilizer ammonium nitrate on common toad (Bufo bufo) tadpoles. Arch Environ Contam Toxicol 32:298-303.

26. Dial NA, Dial CAB. 1987. Lethal effects of diquat and paraquat on developing frog embryos and 15-day-old tadpoles, Rana pipiens. Bull Environ Contam Toxicol 38:1006-1011.

27. Schmuck R, Geise W, Linsenmair KE. 1994. Life-cycle strategies and physiological adjustments of reedfrog tadpoles (Amphibia, Anura, Hyperoliidae) in relation to environmental conditions. Copeia 1994:996-1007.

28. Smith DC. 1987. Adult recruitment in chorus frogs: Effects of size and date at metamorphosis. Ecology 68:344-350.

29. Greulich K, Pflugmacher S. 2003. Differences in susceptibility of various life stages of amphibians to pesticide exposure. Aquat Toxicol 65:329-336.

30. Herkovits J, Pérez-Coll CS. 1993. Stage-dependent susceptibility of Bufo arenarum embryos to cadmium. Bull Environ Contam Toxicol 50:608-611.

31. Anguiano OL, Montagna CM, Chifflet de Llamas M, Gauna L, Pechen de DAngelo AM. 1994. Comparative toxicity of parathion in early embryos and larvae of the toad, Bufo arenarum Hensel. Bull Environ Contam Toxicol 52:649-655.

32. Allran JW, Karasov WH. 2000. Effects of atrazine and nitrate on northern leopard frog (Rana pipiens) larvae exposed in the laboratory from posthatch through metamorphosis. Environ Toxicol Chem 19:2850-2855.

33. Edginton AN, Sheridan PM, Stephenson GR, Thompson DG, Boermans HJ. 2004. Comparative effects of $\mathrm{pH}$ and Vision ${ }^{\circledR}$ herbicide on two life stages of four anuran amphibian species. Environ Toxicol Chem 23:815-822.

34. Bucciarelli T, Sacchetta P, Pennelli A, Cornelio L, Romagnoli R, Merino S, Petruzelli R, Di Ilio C. 1999. Characterization of toad glutathione transferase. Biochim Biophys Acta 1431:189-198.

35. Herkovits J, Fernández A. 1978. Tolerancia a noxas durante el desarrollo embrionario. Medicina (Buenos Aires) 39:400-408.

36. Huey DW, Beitinger TL. 1980. Toxicity of nitrite to larvae of the salamander Ambystoma texanum. Bull Environ Contam Toxicol 25:909-912.

37. Committee on Nitrate Accumulation. 1972. Accumulation of $\mathrm{Ni}$ trate. National Academy of Sciences, Washington, DC.

38. Camargo JA, Ward JV. 1992. Short term toxicity of sodium nitrate $\left(\mathrm{NaNO}_{3}\right)$ to non-target freshwater. Chemosphere 24:23-28.

39. Meyer-Aurich A, Zander P, Werner A, Roth R. 1998. Developing agricultural land use strategies appropriate to nature conservation goals and environmental protection. Landsc Urban Plann 41: 119-127.

40. Cameira MR, Fernando RM, Pereira LS. 2003. Monitoring water and $\mathrm{NO}_{3}-\mathrm{N}$ in irrigated maize fields in the Sorraia Watershed, Portugal. Agric Water Manag 60:199-216. 